\title{
Tari Bandol Kabupaten Magetan (Sejarah, Nilai Filosofis Dan Potensinya Sebagai Sumber belajar Sejarah Lokal)
}

\section{Valdrin Antariksawan' ${ }^{1}$ dan Soebijantoro ${ }^{2}$}

${ }^{1}$ Alumni Program Studi Pendidikan Sejarah, FKIP, Universitas PGRI Madiun ${ }^{2}$ Dosen Program Studi Pendidikan Sejarah, FKIP, Universitas PGRI Madiun

\begin{abstract}
Abstrak
Penelitian ini bertujuan untuk mengetahui sejarah, nilai filosofis dan potensi tari bandol sebagai sumber belajar sejarah lokal. Penelitian ini menggunakan pendekatan kualitatif dengan jenis penelitian deskriptif kualitatif. Teknik pengumpulan data menggunakan observasi, wawancara, dan analisis dokumen. Validasi data menggunakan triangulasi sumber. Hasil penelitian menunjukkan bahwa tarian bandol diciptakan oleh seniman Kabupaten Magetan yaitu Sarwo Edy Santoso dan Imam Joko. Tari ini menceritakan tentang kegagahan prajurit gondokusuman masa kerajaan Mataram Islam yang melawan penjajah Belanda yang hendak menjajah Kabupaten Magetan. Tari ini memiliki nilai filosofis kepahlawanan, kewibawaan, persatuan, rasa saling peduli, pantang menyerah dan sifat kerjasama (kebaikan). Tari bandol merupakan hasil dari perlombaan tari yang dilakukan dinas pariwisata dan kebudayaan Kabupaten Magetan yang menginginkan adanya tarian khas Kabupaten Magetan. Tari ini sering di tampilkan dalam berbagai acara di Kabupaten Magetan, seperti upacara temu temanten, hari jadi Kabupaten Magetan dan larung sesaji. Tari Bandol sudah dijadikan ekstrakulikuler di sekolah-sekolah di Kabupaten Magetan.
\end{abstract}

Kata Kunci: Tari Bandol, Filosofis, Sejarah Lokal

\section{Pendahuluan}

Kebendaan Pulau Jawa merupakan salah satu pulau terbesar di Indonesia yang mempunyai keanekaragaman seni budaya salah satu nya adalah tarian. Banyak sekali tarian yang berasal dari pulau Jawa khususnya daerah Jawa Timur seperti Tari Pentul Melikan dari Ngawi, Tari Dongkrek dari Madiun, dan Tari Bandol dari Kabupaten Magetan. Setiap Tarian dari setiap daerah di Jawa Timur mempunyai keunikan dan ciri khasnya masing-masing.

Pada umumnya tarian yang berasal dari Jawa Timur diwariskan oleh nenek moyang mereka. Saat ini masih terdapat masyarakat yang masih melestarikan kebudayaan tersebut. Salah satunya adalah Kabupaten Magetan yang merupakan salah satu Kabupaten yang berada di Jawa Timur yang memiliki beragam kesenian. Bahari (2008: 45) mengungkapkan bahwa kesenian adalah salah satu kebutuhan manusia yang tergolong dalam kebutuhan integratif adalah menikmati keindahan, mengapresiasi dan mengungkapkan perasaan keindahan. Kebutuhan ini muncul disebabkan adanya sifat dasar manusia yang ingin mengungkapkan jati dirinya sebagai makhluk hidup yang bermoral, berselera, berakal dan berperasaan.

Banyak cara menuangkan kesenian salah satunya dengan seni tari. Pengertian seni tari menurut Cooric Hartong seorang ahli tari dari Belanda dalam (Bahari 2008: 56) mengungkapkan bahwa seni tari adalah gerak-gerak yang diberi bentuk ritmis dari 
badan dalam ruang. Pemikiran serupa juga disampaikan Kamaladevi Chattopadhaya seorang ahli tari dari India dalam memberi batasan tentang tari yang merupakan desakan perasaan manusia yang mendorongnya untuk mencari ungkapan berupa gerak-gerak yang ritmis (Bahari 2008: 56). Dari beberapa jenis kesenian yang terdapat di Kabupaten Magetan salah satunya adalah Tari Bandol.

Tari Bandol ini digunakan oleh masyarakat Kabupaten Magetan sebagai hiburan dari acara-acara yang diselenggarakan di Kabupaten Magetan antara lain penyambutan pengantin dalam upacara pernikahan (temu temanten), upacara adat larung sesaji, dan juga hari jadi Kabupaten Magetan. Tari Bandol ini masih sering di tampilkan oleh anak-anak sekolah, meski saat ini tidak banyak sekolah yang mementaskannya. Namun Tari Bandol masih dilestarikan hingga saat ini. Tari ini menggambarkan tentang sekelompok pemuda yang mencuri di suatu wilayah.

Pencurian tersebut tidak berjalan lancar karena para pemuda tersebut ketahuan oleh para pemuda yang pandai ilmu kanuragan. Setelah pertarungan yang sengit antara pencuri dan pemuda, pencuri menjelaskan alasan mencuri untuk menolong masyarakat yang kesusahan di daerah mereka. Karena mendengar hal tersebut para pemuda memaafkan pencuri dan bersama-sama memohon ampunan kepada sang pencipta. Wujud tarian bandol ini berupa gerakan silat seperti cerita yang dipaparkan diatas. Berdasarkan cerita tersebut nilai-nilai tari bandol menunjukan rasa saling peduli sesama, kerjasama, tolong menolong dan pantang menyerah masyarakat Kabupaten Magetan. Sehingga saat ini tari Bandol dijadikan sumber pembelajaran di Kabupaten Magetan.

Terbukti dari upaya pemerintah Kabupaten Magetan yang mengadakan sosialisasi dan pelatihan kepada guru-guru SD di Kabupaten Magetan untuk mempelajari tarian ini agar generasi muda selanjutnya dapat mempertahankan kebudayaan Kabupaten Magetan juga menumbuhkan rasa peduli terhadap sesama, sifat kerjasama, tolong menolong dan pantang menyerah. Oleh karena itu Tari Bandol menjadi aset budaya yang dimiliki masyarakat Kabupaten Magetan Jawa.

Meskipun tarian ini sudah banyak ditampilkan dalam upacara-upacara yang diselenggarakan di Kabupaten Magetan. Namun masih belum banyak masyarakat yang mengetahui nilai filosofis dari sebuah tarian serta potensi Tari Bandol sebagai sumber pembelajaran sejarah lokal.

\section{Tinjauan Pustaka}

\section{A. Seni Tari}

\section{Makna Seni Tari}

Menurut Cooric Hartong (dalam Bahari, 2008:56) bahwa seni tari adalah gerak-gerak yang diberi bentuk ritmis dari badan dalam ruang. Kamaladevi 
Chattopadhaya (dalam Bahari, 2008: 56) memberi batasan tentang tari yang merupakan desakan perasaan manusia yang mendorongnya untuk mencari ungkapan berupa gerak-gerak yang ritmis. Pendapat yang sama dikemukakan Hidayat (dalam Sustiawati, 2011: 129) bahwa tari merupakan ungkapan perasaan manusia yang dinyatakan dengan gerak-gerakan tubuh manusia ekspresif yang bertujuan, ditetapkan secara kultural, mengandung ritme, mengandung nilai estetika, dan memiliki potensi simbolik.

$$
\text { Soemaryatmi }
$$

(2007:

mengutarakan seni tari adalah bentuk pernyataan imaginatif yang tertuang lewat kesatuan simbol-simbol gerak, ruang dan waktu. Dalam pengertian ini, gerak wiraga harus dihayati sebagai suatu materi yang dipakai untuk medium ungkap yang paling baku di dalam tari. Didalam suatu struktur gerak tari, maka aneka macam gerak tersebut akan mewujudkan suatu kesatuan yang disebut dengan kesatuan bentuk gerak.

Dalam pengertian tari Jawa, kesatuan bentuk gerak yang paling sederhana disebut istilah unsur gerak tari. Unsur gerak tari tersebut akan membentuk suatu kesatuan tertentu, dimana bentuk dan gaya daripada suatu kesatuan unsur-unsur gerak tersebut akan tampak sedemikian spesifik. Bentuk kesatuan unsur-unsur gerak tari atau ragam gerak tari. Motif gerak tari atau ragam gerak tari adalah suatu gerak yang tersusun dari sebuah kesatuan antara unsur gerak tangan, badan, kepala, dan kaki. Sedangkan gaya dari pada setiap motif gerak ragam gerak tarinya adalah warna (corak) yang timbul dan terbentuk karena adanya kesatuan dari pada sifat geraknya yakni sifat gerak berhenti dan sifat gerak berpindah tempat atau milir, volume gerak, penggunaan dominasi gerak (dominasi gerak tangan, badan dan kaki), variasi arah geraknya, serta penggunaan ritme dan irama geraknya.

Dari beberapa pengertian tersebut dapat disimpulkan bahwa seni tari merupakan bentuk keindahan manusia yang dapat dinikmati dari gerakan yang ritmis. Seni tari juga sebagai bentuk pernyataan imaginatif yang dituangkan melalui simbol gerak, ruang dan waktu yang menjadi satu kesatuan yang saling berkaitan sehingga membentuk gerak yang indah. Seni tari juga memiliki jenis dan fungsinya masingmasing. Seperti halnya tari bandol yang berada di kabupaten Magetan yang merupakan suatu perwujudan ungkapan perasaan jiwa dari manusia yang tertuang melalui gerak-gerak tubuh yang ritmis.

\section{Jenis Seni Tari}

Menurut Kusudiarja (dalam Novitasari, 2017: 51-56) menjelaskan bahwa ada empat macam jenis tari, yaitu:

a) Tari untuk putra dan putri

Setiap daerah atau negara, antara tari untuk putra dan putri terdapat perbedaan. Hal tersebut menunjukkan 
bahwa tari untuk putra banyak dilakukan oleh putri, begitu sebaliknya.

b) Tari untuk upacara keagamaan

Tari ini digunakan untuk menyampaikan rasa bakti manusia kepada Tuhan, misalnya tari Pendhet dari Bali.

c) Tari untuk di pertunjukkan

Tari dipertunjukkan pada segi keindahan dan kehalusan atau kedinamikaannya, misalnya tari lilin dan tari topeng.

d) Tari untuk pergaulan

Tari untuk pergaulan atau hiburan ini biasanya menggunakan gerak dan irama yang sederhana, agar tarian tersebut mudah dipelajari, misalnya tari Tayub dari Jawa Tengah.

\section{Fungsi Tari}

Jazuli (dalam Ratih E.W, 2001: 6869) menggolongkan fungsi tari menjadi empat bagian, yaitu:

a) Tari sebagai sarana upacara

Media persembahan atau pemujaan terhadap kekuatan gaib digunakan oleh masyarakat yang memiliki kepercayaan animisme (roh-roh gaib), dinamisme (benda-benda yang mempunyai kekuatan), dan totemisme (bintangbintang yang dapat mempengaruhi kehidupan), disajikan dalam upacara sakral ini bertujuan untuk mendapatkan keselamatan atau kebahagiaan. Fungsi tari sebagai sarana upacara dapat dibedakan menjadi tiga, yaitu untuk upacara keagamaan, upacara adat berkaitan dengan peristiwa alamiah, dan upacara adat berkaitan dengan peristiwa kehidupan manusia.

b) Tari sebagai hiburan

Untuk memeriahkan atau merayakan pertemuan. Tari yang disajikan bukan pada keindahan geraknya, melainkan segi hiburan. Tari hiburan pada umumnya merupakan tarian pergaulan atau social dance. Pada tari hiburan ini bertujuan untuk memberikan kesempatan penonton yang mempunyai kegemaran menari atau menyalurkan hobi dan mengembangkan keterampilan atau tujuan yang kurang menekankan nilai seni (komersial).

c) Tari sebagai pertunjukan

Tari yang bertujuan untuk membimbing pengalaman estetis kepada penonton. Tari disajikan agar memperoleh apresiasi sebagai hasil seni yang memberi kepuasan ke mata dan hati penonton. Tari sebagai seni pertunjukan memerlukan pengamatan serius dari sekedar untuk hiburan. Untuk itu tari yang tergolong sebagai seni pertunjukan adalah performance. Sebab pertunjukan tari lebih mengutamakan bobot nilai seni dari pada tujuan lain.

d) Tari sebagai media pendidikan

Tari yang bersifat untuk mengembangkan kepekaan estetis melalui kegiatan berapresiasi dan pengalaman berkarya kreatif. 


\section{B. Nilai-Nilai Filosofis}

Menurut Kluckhohn (dalam Hari, 2015:36) nilai merupakan konsepsi, berarti nilai menunjukan susunan yang sesuai dengan adat dan struktur masyarakat. Bukan berarti nilai dapat dilihat melalui adat, tetapi adat seakan-akan merupakan sebagian manifestasi dari nilai yang dianut oleh masyarakat. Tindakan manusia mempunyai hubungan yang konsisiten dengan nilai yang dianut. Nilai banyak di dasarkan pada kegunaan sesuatu dengan pertimbangan kognitif dan bukan melalui pertimbangan emosi atau efeksi.

Nilai merupakan bentuk dasar bagi sebagian besar sikap situasional yang spesifik dan konsekuensinya yang konkrit atau eksistensial, juga merupakan suatu kecenderungan yang mendorong perbuatan individu. Nilai bukan merupakan referensi mutlak bagi individu, tetapi merupakan suatu kecenderungan atau pertimbangan yang dirasakan dan dianggap sebagai sesuatu yang dapat ditentukan secara moral, dengan melihat alasan atau ketentuan estetika.

Roceach dan Bank (dalam Lubis, 2008: 16-17) menjelaskan nilai adalah tipe kepercayaan yang berada dalam ruang lingkup sistem kepercayaan, dimana seseorang harus bertindak atau menghindari suatu tindakan, atau mengenai suatu yang pantas atau tidak pantas dikerjakan, dimiliki dan dipercayai. Nilai itu merupakan sifat melekat pada sesuatu yang telah berhubungan dengan subyek (manusia pemberi nilai). Fraenkel (dalam Lubis, 2008: 17) berpendapat standar tingkah laku, keindahan, kebenaran dan efesiensi yang mengikat manusia dan sepatutnya dijalankan dan dipertahankan. Sedangkan Noeng Muhadjir (dalam Lubis, 2011:18) mengemukakan berdasarkan pendekatan budaya manusia, nilai hidup dapat dibagi ke dalam tujuh kategori, yakni: nilai ilmu pengetahuan, ekonomi, keindahan, politik, keagamaan, kekeluargaan, dan kejasmanian.

Selanjutnya makna filosofi menurut KnelLer (dalam Suprihatin, 2007: 51) adalah upaya berpikir dalam tataran umum dengan cara sistematik alam semesta atau realitas. Upaya tersebut disebabkan adanya ingin tahu manusia. filosofi membantu manusia dalam mengorganisasikan gagasan dan menemukan makna dalam pikiran atau tindakan.

Pemikiran yang dikemukakan Kneller juga menyatakan filosofi tidak hanya sebagaian dari pengetahuan kita atas seni, ilmu alam dan agama. Filosofi bahkan menggenggam semua disiplin tersebut dalam tingkat teoritis dan menemukan serta menjelaskan dan membangun hubungan antara mereka.

\section{Sejarah Lokal}

Menurut priyadi (2012: 6-7) pengertian lokal tidak berbelit-belit seperti daerah atau regional. Istilah lokal mempunyai arti suatu tempat, atau ruang 
sehingga sejarah lokal menyangkut lokalitas tertentu yang disepakati oleh sejarahwan dengan alasan ilmiah, misalnya ruang tempat tinggal suku atau subsuku bangsa. Ruang bisa lintas kecamatan, kabupaten atau provinsi. Ruang sejarah lokal merupakan lingkup geografis yang dibatasi sendiri oleh sejarahwan dengan alasan yang dapat diterima semua orang.

Pendapat yang lain diungkapkan Abdullah (2005: 15), kata lokal tidak berbelit-belit, hanya tempat, ruang. Jadi sejarah lokal adalah sejarah dari tempat yang batasannya ditentukan oleh perjanjian yang diajukan oleh penulis sejarah. Batasan geografisnya dapat tempat tinggal suku bangsa, yang kini mungkin telah mencakup dua atau tiga daerah administratif tingkat dua atau tingkat satu (suku bangsa jawa umpamanya) dan dapat pula suatu kota, atau suatu desa.

Secara sederhana sejarah lokal dirumuskan sebagai kisah kelampuan dari kelompok masyarakat yang berada daerah geografis yang terbatas. Sedangkan menurut Leicester dalam Priyadi (2012:7) menyatakan bahwa sejarah lokal adalah asal-usul, pertumbuhan, kemunduran dan kejatuhan dari kelompok masyarakat lokal.

Dapat disimpulkan bahwa pengertian sejarah lokal adalah suatu kegiatan disuatu daerah tertentu yang mencangkup lokalitas tertentu yang disepakati oleh penulis sejarah, atau sejarahwan dengan alasanalasan ilmiah, misalnya suatu ruang tempat tinggal suku bangsa atau subsuku bangsa. Sejarah lokal di Indonesia sejak 1950 menurut Abdullah (dalam Novitasari, 2017: 56-57) mengatakan corak studi sejarah lokal dibedakan empat corak, yaitu:

1. Studi yang difokuskan pada peristiwa tertentu (studi peristiwa khusus atau apa yang disebut evenemental l'evenement).

2. Studi yang menekankan pada stuktur.

3. Studi yang mengambil perkembangan aspek tertentu dalam kurun waktu tertentu (studi tematis), dan

4. Studi sejarah umum, yang menguraikan perkembangan daerah tertentu (propinsi, kota, kabupaten).

\section{Metode Penelitian}

Lokasi penelitian di Kabupaten Magetan tepatnya di SMKN 2 Magetan Kecamatan Magetan Kabupaten Magetan. Lokasi penelitian berjarak kurang lebih 300 m dari pusat kota Magetan. Penelitian ini menggunakan pendekatan kualitatif. Satori dan Komariah (2012: 22) menyatakan penelitian kualitatif adalah penelitian yang menekankan pada quality atau hal yang terpenting dari sifat suatu barang/jasa.

Menurut Sugiyono (2010: 14) metode penelitian kualitatif disebut metode penelitian naturallistik karena penelitiannya dilakukan pada kondisi yang alamiah. Sering disebut metode etnographi, karena awalnya metode ini banyak digunakan untuk penelitian dibidang antropologi budaya. Disebut metode kualitatif karena data yang 
terkumpul dan analisisnya bersifat kualitatif. Pendekatan ini dirasa tepat karena untuk menganalisis data yang diperoleh dari wawancara, dokumentasi, dan observasi lapangan.

Sumber data penelitian ini adalah subyek darimana data dapat diperoleh (Arikunto, 2014: 172). Sumber data dibagi menjadi dua, yaitu Sumber Primer adalah sumber data yang langsung memberikan data kepada peneliti Satori dan Komariah (2012:103). Sumber data primer di peroleh dari Kepala sekolah SDN Bulukerto 2, guru seni SDN Bulukerto 2 dan warga desa Bulukerto, sedangkan data sekunder berupa sumber pustaka dari dokumen-dokumen.

Selanjutnya data diolah agar mudah dibaca dan dimengerti oleh orang lain atau pengambil keputusan, perlu ditampilkan dalam bentuk tertentu (Hasan dan Misbahuddin, 2013: 29). Terdapat 2 bentuk penyajian data yaitu:

a. Tabel data

Tabel data adalah penyajian data dalam bentuk kumpulan angka disusun menurut kategori tertentu dalam daftar.

b. Grafik data

Disebut diagram data adalah penyajian data dalam bentuk gambar.

Untuk pengumpulan data menggunakan beberapa teknik, yaitu: 1). Observasi berkenaan dengan perilaku manusia, proses kerja, gejala alam dan responden yang diamati tidak terlalu besar,

2). Wawancara dalam penelitian menggunakan wawancara tidak terstruktur. Beberapa informan yang digunakan adalah Dinas Kebudayaan Kabupaten Magetan, Dinas Pendidikan Kabupaten Magetan, Guru Seni Tari SMKN 2 Magetan, 3). Analisis dokumen berupa profil kota, foto serta data statistik Kabupaten Magetan.

Teknik analisis data dalam penelitian kualitatif dilakukan sejak sebelum memasuki lapangan, selama di lapangan, dan setelah di lapangan. Dalam teknik analisis data terdapat tiga komponen yakni: Reduksi data, Penyajian data (display data), dan penarikan kesimpulan (tahap penemuan hasil).

\section{Hasil Dan Pembahasan}

\section{A. Gambaran Singkat Kabupaten Magetan}

Kabupaten Magetan merupakan salah satu wilayah eks-Karesidenan Madiun yang terletak di kaki gunung Lawu sebelah timur membentang dari selatan ke utara. oleh sebab itu Kabupaten Magetan dikenal dengan Green Belt Lawu atau lingkar hijau Lawu. Ibukota Kabupaten Magetan terletak di Kelurahan/Kecamatan Magetan.

Batas wilayah Kabupaten Magetan dari sebelah barat Kabupaten Karanganyar (Provinsi Jawa Tengah) sedangkan sebelah selatan Kabupaten Ponorogo dan Kabupaten Wonogiri (Provinsi Jawa Tengah) lalu sebelah timur Kabupaten Madiun dan Sebelah utara Kabupaten Ngawi. Secara geografis, Kabupaten Magetan terletak antara $70^{\circ} 38^{\prime} 30^{\prime \prime}$ lintang selatan dan $111^{\circ}$ 
20' 30" bujur timur dengan ketinggian antara 660 s/d 1.660 meter di atas permukaan air laut. Kabupaten Magetan memiliki wilayah seluas $688,85 \mathrm{~km} 2$. Secara administratif letak Kabupaten Magetan terbagi menjadi sebanyak 18 Kecamatan, 208 Desa dan 27 Kelurahan (235 Desa/Kelurahan), 1.048 RW dan 4.710 RT.

\section{B. Sejarah Tari Bandol Periode 2013- 2017}

Tari Bandol merupakan aset seni budaya yang dimiliki oleh Kabupaten Magetan. Tari bandol ini digunakan oleh masyarakat Kabupaten Magetan sebagai hiburan dalam acara-acara yang diselenggarakan di Kabupaten Magetan antara lain penyambutan pengantin dalam upacara pernikahan (temu temanten), upacara adat larung sesaji, dan juga hari jadi Kabupaten Magetan. Awal mula terciptanya tari bandol berawal dari keinginan Pemerintah Kabupaten Magetan yang menginginkan sebuah tarian untuk penyambutan dalam upacra yang ada di Kabupaten Magetan. Sebuah tarian yang lucu dan disukai oleh para tamu undangan.

Hal ini membuat para seniman tari di Kabupaten Magetan berlomba-lomba untuk membuat sebuah tarian yang lucu dan dapat disukai oleh para tamu undangan yang datang di Kabupaten Magetan. Dua orang seniman yaitu Sarwo Edy Santoso dan Imam Joko berhasil membuat tarian tersebut dan menamai tarian tersebut dengan nama tari bandol yang memiliki arti membawa arti dari membawa sendiri berarti membawa rasa aman dan tentram. Tarian ini menceritakan tentang kegagahan prajurit Gondokusuman pada masa kerajaan Mataram Islam yang ingin mempertahankan bumi pertiwi Magetan dari penjajahan yang dilakukan oleh Belanda.

Untuk itu para prajurit Gondokusuman berupaya memperkuat pertahanan dan olah kanuragan demi melindungi bumi Magetan dari penjajahan Belanda sehingga membuat masyarakat Magetan merasa aman dan tentram. Meskipun gerakan tari bandol ini terkesan lucu dan slengekan namun tidak meninggalkan kesan gagahnya kesatria Magetan. Gerakan pada tari ini memang di buat lucu dan jenaka hal ini dikarenakan tarian ini adalah tari hiburan yang bersifat menghibur para tamu undangan yang datang ke Kabupaten Magetan.

Selain gerakan, alat musik dan pakaian yang digunakan juga sangat mendukung gerakan yang dilakukan penari. Alat musik yang digunakan adalah gamelan jawa slendro dengan dominan bonang dan pakaian yang digunakan adalah lurik, jarik, iket kepala dan topeng gecul. Perkembangan tari bandol dari 
tahun 2013-2017 banyak sekali mengalami perubahan. Pada awalnya tari ini hanya dimainkan oleh pria saja dikarenakan gerakan tari ini yang kebanyakan menggunakan gerakan kanuragan. Akan tetapi pada saat ini tari ini juga dimainkan oleh wanita juga bukan hanya dari penarinya saja akan tetapi musik yang digunakan juga mengalami perubahan. Pada awal nya tari bandol ini menggunakan musik dari bonang dan slendro akan tetapi saat ini hanya munggunakan VCD dikarenakan lebih mudah digunakan

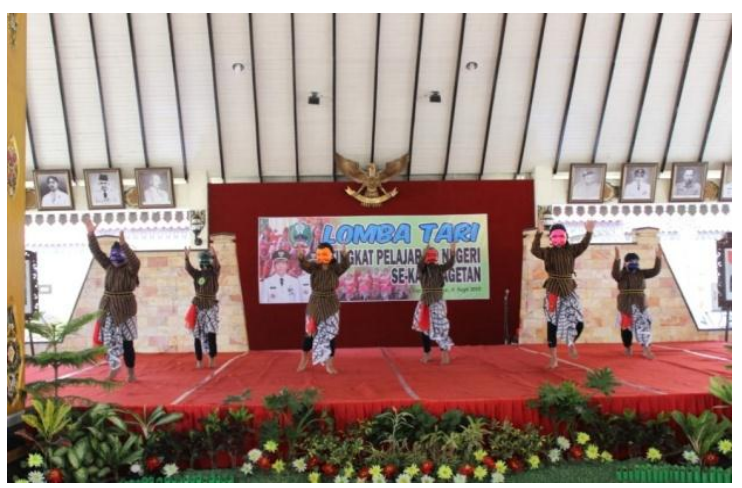

Gambar 1. Tari Bandol

(Dinas Kebudayaan Kabupaten Magetan)

\section{Nilai-nilai Filosofis Tari Bandol}

Nilai-nilai filosofis yang terkandung dalam tari bandol yaitu:

1. Kepahlawanan

Kepahlawanan disini adalah kepahlawanan prajurit gondokusuman yang rela mengorbankan nyawa melawan penjajah Belanda demi keamanan dan ketentraman rakyat Magetan agar tidak dijajah oleh belanda yang ingin menguasai daerah Magetan dan ingin mengambil sumber daya alam Magetan sebagai daerah yang subur untuk ditanami berbagai jenis tanaman seperti tebu, padi, dan tanaman lainnya.

2. Kewibawaan

Kewibawaan yang dimiliki oleh prajurit gondokusuman atau prajurit Magetan yang tidak mau tunduk kepada penjajah Belanda dan tetap mempertahankan kewibawaan prajurit gondokusuman.

3. Persatuan

Persatuan disini adalah persatuan dari rakyat Magetan dan prajurit gondokusuman untuk membela tanah air mereka dari penjajahan Belanda yang ingin menjajah magetan

4. Rasa saling peduli terhadap sesama

Terlihat pada tarian ini yang menunjukan kepedulian prajurit gondokusuman terhadap rakyat magetan dan pada akhirnya harus melawan penjajah Belanda.

5. Sifat pantang menyerah prajurit Gondokusuman atau prajurit Kabupaten magetan untuk mengusir penjajah Belanda dari bumi pertiwi Magetan.

6. Tampilan jenaka dan lucu

Tampilan jenaka dan lucu pada tarian ini lebih sebagai hiburan. Akan tetapi mempunyai arti juga bahwa prajurit gondokusuman memberikan rasa aman dan tentram kepada rakyat Magetan. 
Pada prinsipnya nilai-nilai filosofis yang terdapat pada tari bandol adalah persatuan dan kesatuan rakyat Kabupaten Magetan dan rasa saling peduli juga sifat kerjasama untuk melindungi wilayah dari ancaman penjajah Belanda yang ingin menjajah Kabupaten Magetan dan juga melihatkan nilai-nilai kepahlawanan dan kewibawaan prajurit gondokusuman dalam melawan penjajahan belanda yang ingin menjajah Magetan.

\section{Potensi Tari Bandol Sebagai Sumber Sejarah Lokal}

Tari bandol merupakan tari yang menceritakan tentang perlawanan prajurit Gondokusuman dan rakyat Magetan dalam mengusir penjajah Belanda. Tari bandol sudah dipelajari oleh guru-guru yang berada di Kabupaten Magetan. Pemerintah Kabupaten Magetan melalui Dinas Pariwisata dan Kebudayaan mengadakan pelatihan tari bandol untuk guru di lingkup Kabupaten Magetan dengan tujuan mengenalkan tari bandol sebagai tari khas Kabupaten Magetan.

Namun demikian kebanyakan guru yang dilatih rata-rata adalah perempuan. Sedangkan untuk tari bandol sendiri identik dengan laki-laki sebagai penarinya karena lebih cocok menggambarkan sosok kesatria. Tari bandol ini oleh pemerintah Kabupaten Magetan dijadikan sebagai ekstrakulikuler di sekolah Sekabupaten Magetan, yang nantinya akan ada wacana tari bandol tersebut menjadi salah satu ekstrakulikuler wajib di sekolah Kabupaten Magetan. Ditinjau dari beberapa aspek yang ada, baik dari hasil wawancara, foto maupun nilai filosofis yang terkandung dalam tari bandol di Kabupaten Magetan.

Ada potensi bahwa tari bandol khas Kabupaten Magetan bisa digunakan sebagai materi tambahan dalam pembelajaran sejarah dengan materi kolonialisme dan imperialisme dengan standard kompetensi 5.1 (Mengembangkan nilai dan perilaku mempertahankan harga diri bangsa, mengelola alam, lingkungan hidup dengan bercermin pada kegigihan para pejuang dalam melawan penjajah) Dan Kompetensi dasar 5.1 (Menganalisis strategi perlawanan bangsa Indonesia terhadap penjajahan bangsa Barat di Indonesia sebelum dan sesudah abad ke-20). Pada siswa kelas XI semester I. Diharapkan juga dari adanya potensi tari bandol sebagai sumber belajar sejarah lokal, peserta didik akan tau sejarah yang ada di sekitar lingkungannya. Dengan ilmu pengetahuan yang didapatkan diharapkan generasi muda nantinya mau melestarikan kebudayaan yang merupakan warisan dari nenek moyang mereka.

\section{Penutup}

Tari bandol adalah tari yang berasal dari Kabupaten Magetan. Tari ini diciptakan oleh dua orang seniman yaitu Sarwo Edy Santoso dan Imam Joko Tari Bandol ini digunakan oleh masyarakat Kabupaten Magetan sebagai hiburan dari acara-acara 
yang diselenggarakan di Kabupaten Magetan antara lain penyambutan pengantin dalam upacara pernikahan (temu temanten), upacara adat larung sesaji, dan juga hari jadi Kabupaten Magetan. Tari Bandol ini masih sering di tampilkan oleh anak-anak sekolah meski saat ini tidak banyak sekolah yang mementaskannya lagi akan tetapi Tari Bandol masih dilestarikan hingga saat ini.

Tarian ini menceritakan tentang kegagahan prajurit Gondokusuman pada masa penjajahan Belanda yang ingin mempertahankan bumi pertiwi Magetan dari penjajahan yang dilakukan oleh Belanda. Gondokusuman sendiri adalah nama organisasi yang ada di Kabupaten Magetan. Untuk itu para prajurit gondokusuman berupaya memperkuat pertahanan dan olah kanuragan demi melindungi bumi Magetan dari penjajahan Belanda yang ingin mengusai kekayaan alam Magetan yang terkenal tanahnya subur untuk ditanamin berbagai jenis tanaman.

Tarian ini memberikan nilai filosofis yang pantas untuk dipelajari oleh generasi muda yaitu nilai kepahlawanan, kewibawaan, persatuan, rasa saling peduli, pantang menyerah dan sifat kerjasama dalam hal kebaikansuro. Sehingga saat ini tari Bandol dijadikan sumber pembelajaran di Kabupaten Magetan Di SMK sederajat khususnya kelas XI semester genap. Terbukti dari upaya pemerintah
Kabupaten Magetan yang mengadakan sosialisasi dan pelatihan kepada guru-guru di Kabupaten Magetan untuk mempelajari tarian ini agar generasi muda.

Selanjutnya dapat mempertahankan kebudayaan Kabupaten Magetan juga menumbuhkan rasa saling peduli terhadap sesama, kerjasama, tolong menolong dan pantang menyerah masyarakat Kabupaten Magetan. Oleh sebab itu Tari Bandol menjadi aset budaya masyarakat Kabupaten Magetan Jawa Timur

\section{Daftar Pustaka}

Aan Komariah dan Djam`an Satori. 2010. Metodologi Penelitian Kualitatif. Alfabeta: Bandung

Abdullah, T. 2005. Sejarah Lokal Di Indonesia. Yogyakarta: Gajah Mada University Press.

Arikunto, S. 2014. Prosedur Penelitian: Suatu Pendekatan Praktik. Jakarta: Rineka Cipta.

Bahari, N. 2008. Kritik Seni Wacana Apresiasi Dan Kreasi. Yogyakarta: Pustaka Pelajar.

Hari, A, H. 2015. Peran Nilai-Nilai Personal (Personal Values) terhadap Sikap Konsumen. Jurnal Magistra. (92) 3536.

Hasan., Misbahuddin. 2013. Analisis Data Penelitian Dengan Statistik. Jakarta: PT Bumi Aksara.

Lubis, M. 2008. Evaluasi Pendidikan Nilai Perkembangan Moral Keagamaan Mahasiswa TAIN. Yogyakarta: Pustaka Belajar.

Novitasari,R.T.A., Hanif, M. 2017. Tari Kecetan Dalam Tradisi Keduk Beji Desa Tawun Kecamatan Kasreman Kabupaten Ngawi (Makna 
Simbolis, Dan Sumber Pembelajaran Sejarah Lokal. Agastya: Jurnal Sejarah dan Pembelajarannya. 7 (1). 51-57. Diunduh pada 12 maret 2017/www.portalgaruda.co.org

Priyadi, S. 2012. Sejarah Lokal Konsep, Metode Dan Tantangannya. Yogyakarta: Penerbit Ombak

Ratih,E.W. 2001. Fungsi Tari Sebagai Seni Pertunjukan. Jurnal Pengetahuan dan Pemikiran Seni. 2 (2). 68-69. Diunduh pada 12 maret 2017/www.portalgaruda.co.org

Satori, D., Komariah, A. 2012. Metodologi Penelitian Kualitatif. Bandung: Alfabeta

Soemaryatmi. 2007. Wiraga Tunggal Tari Gaya Yogyakarta. Solo: Isi Press

Sugiyono. 2010. Metode Penelitian Pendidikan (Pendekatan Kuantitatif, Kualitatif dan R\&D). Bandung: Alfabeta

Supriyatin, E, W. 2007. Filosofi Sebagai Landasan Pengembangan Kurikulum. Jurnal Management Pendidikan. (01) 48-51. Diunduh pada: $\quad 11 \quad$ Maret 2017/www.portalgaruda.org

Sustiawati, N, L. 2011. Kontribusi Seni Tari Nusantara Dalam Membangun Pendidikan Multikultur. Mudra. (26) 126-130. Diunduh pada: 11 Maret 2017/www.portalgaruda.org 